\title{
Penerapan Model Pembelajaran Kontekstual Materi Batuan dalam Meningkatkan Hasil Belajar Siswa SMAN 9 Binsus Manado
}

\author{
Denny Maliangkay \\ Program Studi Geografi, Fakultas Ilmu Sosial, Universitas Negeri Manado \\ e-mail: dennymaliangkay@unima.ac.id
}

\begin{abstract}
Contextual Teaching and Learning can help teachers connect learning material with the real environment to students. The purpose of this study was to determine the application of the CTL contextual learning model and the environment as a learning resource in increasing students' understanding of geography learning, especially about rock types. Activities were carried out for 3 months. This type of research is Classroom Action Research, which consists of 3 cycles. Cycle I, the teacher shows the rock type while explaining and the students work on the question cards, in the second cycle the students observe, identify, and classify the rock types by working on the worksheets in a group worksheet outside the classroom or school environment then presenting the results of group discussions and cycle III, students They were assigned to bring 10 different rock types from the house and then observed, identified and grouped by doing the LKS then presented in front of the class while showing the types of rocks one by one individually according to the LKS. The findings show that there is an increase in student understanding due to the motivation and learning activities of students in making observations, identifying or classifying rock types, and working on worksheets both in groups and individually. At the end of the action, based on the indicators of success, it was proven that the actions given were successful in increasing students' understanding to achieve classical completeness. In the post-test before applying the CTL approach, students' learning completeness was $20 \%$, after being given post-test action in the first cycle the completeness was $48.57 \%$, the second cycle was $74.20 \%$ and in the third cycle $88.57 \%$. Therefore, if you want to improve students' understanding of rock types, you can apply the contextual learning model approach.
\end{abstract}

Keywords: Contextual Teaching and Learning, Learning Outcomes, Geography Learning, Rocks

\begin{abstract}
Abstrak: Model Pembelajaran kontekstual (Contextual Teaching and Learning) dapat membantu guru dalam menghubungkan antara materi pembelajaran dengan lingkungan nyata kepada siswa. Tujuan dalam penelitian ini adalah untuk mengetahui penerapan Model Pembelajaran kontekstual CTL dan lingkungan sebagai sumber belajar dalam meningkatkan pemahaman siswa dalam pembelajaran geografi khususnya tentang jenis batuan. Kegiatan dilaksanakan selama 3 bulan. Jenis Penelitian adalah Penelitian Tindakan Kelas, yang terdiri atas 3 siklus. Siklus I, guru menunjukkan jenis batuan sambil menjelaskan dan siswa mengerjakan kartu soal, siklus II siswa mengamati, mengidentifikasi, dan mengelompokan jenis batuan dengan mengerjakan tabel kerja pada LKS secara berkelompok di luar kelas atau lingkungan sekolah kemudian mempresentasikan hasil diskusi kelompok dan siklus III, siswa ditugaskan membawa 10 jenis batuan yang berbeda dari rumah kemudian diamati, diidentifikasi dan dikelompokan dengan mengerjakan LKS lalu dipresentasikan di depan kelas sambil menunjukkan jenis batuan satu persatu secara individu sesuai LKS. Hasil temuan menunjukkan bahwa terjadi peningkatan pemahaman siswa akibat motivasi dan aktivitas belajar siswa dalam melakukan pengamatan, mengidentifikasi atau mengelompokan jenis batuan dan mengerjakan soal LKS baik secara kelompok maupun individu. Pada akhir tindakan, berdasarkan indikator keberhasilan terbukti bahwa tindakan yang diberikan berhasil meningkatkan pemahaman siswa hingga mencapai ketuntasan secara klasikal. Pada post-test sebelum menerapkan pendekatan CTL, ketuntasan belajar siswa adalah $20 \%$, setelah diberikan tindakan post-test pada siklus I ketuntasannya $48,57 \%$, siklus II $74,20 \%$ dan pada siklus III $88,57 \%$. Oleh karena itu, apabila hendak meningkatkan pemahaman siswa tentang jenis batuan dapat menerapkan pendekatan Model Pembelajaran kontekstual.
\end{abstract}

Kata Kunci: Contextual Teaching and Learning, Hasil Belajar, Pembelajaran Geografi, Batuan 